\title{
BENTUK PARTISIPASI POLITIK MASYARAKAT TIONGHOA DI PROVINSI KEPULAUAN BANGKA BELITUNG DALAM PEMILU 2019
}

\author{
Dini Aulia \\ Universitas Bangka Belitung \\ diniaulia2508@gmail.com \\ Raden Ayu Indah Tamara \\ Universitas Bangka Belitung \\ indahtamara0608@gmail.com
}

\begin{abstract}
Abstrak
Studi ini tentang bagaimana bentuk partisipasi politik masyarakat etnis Tionghoa di Provinsi Bangka Belitung. Hal tersebut didasari oleh mayoritas masyarakat etnis Tionghoa yang berada di Bangka Beitung, sehingga kita akan melihat bagaimana partisipasi politik mereka terutama menjelang PEMILU 2019 ini. Pemilu merupakan salah satu wujud dari demokrasi yang menginterpretasikan partisipasi masyarakat dalam menghidupkan sistem demokrasi. Partisipasi politik sangat mempengaruhi sistem politik sebuah negara yang demokratis, karena sistem politik yang demokratis tidak akan ada artinya tanpa adanya partisipasi politik. Beragam bentuk partisipasi politik masyarakat etnis Tionghoa mulai dari menggunakan suara hak pilih, bergabung dalam organisasi partai dan aktivitas kampanye hingga mencalonkan diri sebagai salah satu kandidat.
\end{abstract}

Kata Kunci :Partisipasi, Pemilu, Demokrasi, Masyarakat Etnis Tionghoa

\begin{abstract}
This study about the form of political participation of the ethnic Chinese community in Province of Bangka Belitung. This is based on the majority of the Chinese ethnic community who are in Bangka Belitung, so we will see how their political is especially ahead of this 2019 electon. The election is a manifestation of democracy that reflects community participation in reviving a democratic system. Political participation greatly influences the political system of a democratic country, because a democratic political system will haven't meaning without political participation. Various forms of political participation of the ethnic Chinese community starting from using voting rights, join party organization and campaign to run as one of the candidates.
\end{abstract}

Keywords : Political participation, Bangka Belitung, Chinese ethnic community.

Scripta : Jurnal Ilmiah Mahasiswa Fakultas Ilmu Sosial dan Ilmu Politik

Universitas Bangka Belitung

ISSN: 2656-9809 


\section{PENDAHULUAN}

Pemilu merupakan salah satu wujud dari demokrasi yang mengintrepretasikan partisipasi masyarakat dalam menghidupkan sistem demokrasi. Jika merujuk pada peraturan negara, Pemilu menurut Undang-Undang Nomor 15 Tahun 2011 merupakan sarana pelaksanaan kedaulatan rakyat yang diselenggarakan secara langsung, umum, bebas, rahasia, jujur, dan adil dalam Negara Kesatuan Republik Indonesia berdasarkan Pancasila dan Undang-Undang Dasar Republik Indonesia Tahun 1945. Partisipasi politik merupakan hal yang menarik untuk diperhatikan, dapat dilihat dari banyaknya para ilmuwan yang meneliti tentang hal tersebut. Dalam analisis politik modern, partisipasi termasuk ke dalam hal penting yang belakangan ini banyak mendapat perhatian di negaranegara berkembang.

Partisipasi politik sangat mempengaruhi sistem politik sebuah negara yang demokratis, karena sistem politik yang demokratis tidak akan ada artinya tanpa adanya partisipasi politik. Sehingga apa yang dilakukan rakyat dalam partisipasinya menunjukkan derajat kepentingan mereka. Sebenarnya apa yang dilakukan masyarakat dalam kegiatan politiknya, tidak lebih dari sebuah ungkapan tanggung jawab mereka terhadap keberlangsungan gerak dari pemerintah. Banyak masyarakat yang merefleksikannnya dalam bentuk partisipasi aktif politik

Gejala ini sesuai dengan konsep partisipasi politik itu sendiri, dimana kegiatan dan aktifitas individu sebagai warga negara yang berusaha mempengaruhi pembuatan keputusan pemerintah. Pengaruh terhadap pemerintah dapat mewujudkan perubahan dalam sistem politik Indonesia. Hal ini dapat dilakukan dengan kekuatan politik. Salah satu dari kekuatan politik yang adalah masyarakat dan partisipasinya. Rumusan masalah dalam penelitian ini adalah bagaimana bentuk partisipasi politik masyarakat Etnis Tionghoa di Provinsi Bangka Belitung pada pemilu serentak 2019 ?

Kerangka Teori menggunakan teori dari Huntington dan Nelson (1994:4) mendefinisikan tentang partisipasi, partisipasi politik merupakan kegiatan yang dilakukan oleh warga negara preman, warga negara preman yang dimaksud adalah warga negara biasa yang bukan pejabat. Ramlan Surbakti yang mengutip pendapat Samuel P. Huntington dan Joan N. Nelson membagi basis partisipasi politik secara kolektif dapat di bagi lima, yaitu: (1) Kelas (individual yang memiliki status sosial), (2) Pendapatan dan pekerjaan yang sama, (3) Tetangga, (4) Kelompok-kelompok komunal (individu-individu yang 
berasal dari ras, etnik, agama, dan bahasa yang sama), partai politik, (5) Faksi (pengelompokan patron anak buah atau patron clien group). Partisipasi politik sangat erat kaitannya dengan pemilihan umum karena partipasi politik adalah penentu keberhasilan pelaksanaan demokrasi.

Imawan (2003:4-5) mengungkapkan bahwa partisipasi adalah ciri terpenting demokrasi. Artinya tidak ada partisipasi berarti tidak ada demokrasi. Tanpa adanya parisipasi mustahil produk-produk kebijakan yang dikeluarkan pemerintah dapat memenuhi rasa keadilan warga negaranya. Bentuk partisipaasi politik yang paling umum dikenal adalah pemungutan suara (voting) entah untuk memilih calon wakil rakyat atau untuk memilih kepala negara (Maran, 2001:148). Jadi pemungutan suara seringkali di anggap sebagai bentuk partisipasi politik yang paling mudah untuk dilaksanakan, dibandingkan dengan aktivitas-aktivitas politik lain. Masyarakat menganggap pemungutan suara sebagai hal utama atau partisipasi politik yang utama yang biasa dilaksanakan oleh masyarakat.

Milbrath dan Goel (dalam Sahid, 2001:181) membedakan partisipasi politik dalam beberapa kategori berdasarkan kadar dan jenis aktivitasnya yang pertama yaitu apatis (masa bodoh), apatis adalah seseorang yang menarik diri dari aktivitas politik. Orang yang apatis biasanya acuh dengan kegiatan politik yang ada di sekitarnya. Cholisin dkk (2007:153) menyatakan, bahwa partisipasi politik dapat dikategorikan berdasarkan jumlah pelaku, yakni individual dan kolektif. Partisipasi kolektif dibedakan menjadi dua yakni partisipasi kolektif yang konvensional dan partisipasi kolektif yang nonkonvensional.

\section{METODE PENELITIAN}

\section{Jenis Penelitian}

Penelitian ini menggunakan pendekatan kualitatif. Metode penelitian kualitatif adalah metode penelitian yang digunakan untuk meneliti pada kondisi obyek yang alamiah di mana peneliti berperan sebagai instrumen kunci, dengan teknik pengumpulan data yang dilakukan secara gabungan dan analisis data bersifat induktif guna memperoleh hasil penelitian yang lebih menekankan makna daripada generalisasi.

\section{Waktu dan Tempat Penelitian}

Pencarian data dalam penelitian ini dilakukan beberapa bulan sebelum Pemilu Serentak 2019 dilakukan yakni pada bulan Januari hingga Febuari 2019. Lokasi atau 
tempat penelitian dilakukan pada beberapa daerah di Provinsi Kepulauan Bangka Belitung, yang merupakan tempat dengan penduduk tionghoa terbesar di Indonesia.

\section{Prosedur}

Metode dalam sebuah penelitian diperlukan dalam upaya memperoleh data yang benar-benar obyektif dan dapat dipertanggung jawabkan kebenarannya. Penulis menggunakan penelitian yang bersifat deskriptif kualitatif, metode pendekatan yang digunakan dalam penelitian ialah pendekatan survey.

\section{Data, Instrumen, dan Teknik Pengumpulan Data}

Teknik pengumpulan data yang digunakan dalam penelitian ini adalah wawancara, observasi, dan dokumen. Wawancara diperlukan untuk mengetahui secara langsung bagaimana bentuk partisipasi masyarakat tionghoa yang ada di Kota Pangkalpinang. Observasi atau pengamatan dilakukan selama beberapa minggu sebelum Pemilu Serentak 2019 dilakukan, sedangkan dokumen sebagai data sekunder diperlukan untuk memperkuat data sebelumnya.

\section{Teknik Analisis Data}

Setelah data-data yang diperlukan terkumpul, selanjutnya dilakukan analisis data yang telah diproses tersebut. Metode analisa data yang digunakan oleh penulis adalah metode deskriptif kuantitatif yaitu, data yang dihimpun dengan cara diuraikan diatas, kemudian diolah dengan cara diseleksi, diklasifikasi, secara sistematis dan logis, guna mendapatkan gambaran secara general untuk mendukung makalah yang ditulis melalui analisa data kualitatif dan informasi dari hasil penelitian dibuat dalam bentuk kalimat yang disusun secara sistematis melalui diagram yang dilampirkan dengan harapan dapat ditarik kesimpulan yang tepat.

\section{HASIL PENELITIAN DAN PEMBAHASAN}

Masyarakat Tionghoa mulai bermigrasi keluar Tiongkok antara abad ke-12 dan ke13. Ada enam faktor penyebab pindahnya orang Tionghoa keluar Tiongkok. Pertama, perkembangan bahari dan niaga Tiongkok memungkinkan orang Tionghoa mengunjungi berbagai tempat di dunia. Kedua, interaksi Tiongkok dengan Asia Tenggara menyebabkan wilayah ini menjadi menarik untuk dihuni. Ketiga, pertumbuhan penduduk Tionghoa mempersempit peluang untuk mencari nafkah. Keempat, perluasan militer dan industri Negara barat seperti Amerika Utara dan Inggris menyebabkan timbulnya peluang kerja

Scripta : Jurnal Ilmiah Mahasiswa Fakultas Ilmu Sosial dan Ilmu Politik Universitas Bangka Belitung ISSN: 2656-9809 
untuk tenaga kerja Tionghoa. Kelima, kehadiran perusahaan pelayaran Eropa di Tiongkok memperlancar kerjasama di bidang perdagangan dengan terjadinya pertukaran barang dan jasa. Keenam, guncangan dalam negeri mendorong migrasi besar-besaran dari Tiongkok keluar negeri.

Dengan bergeraknya Indonesia kearah demokrasi konstitusi sesudah proklamasi kemerdekaan negeri ini dari kekuasaan Belanda pada 17 agustus 1945, demokrasi yang barulahir di bawah pimpinan Soekarno, presiden pertama Indonesia, sadarakan masalah yang dihadapi orang Tionghoa mengenai kewarganegaraan mereka. Perundingan Meja Bundar di tahun 1949 pertama-tama mengangkat masalah kewarganegaraan orang Tionghoa yang tinggal di Indonesia. Menurut ketetapannya, nyaris semua orang Tionghoa yang lahir di Indonesia diberikan kebebasan untuk memilih kewarganegaraan. Mereka dapat memperoleh kewarganegaraan Indonesia secara otomatis, atau menetapkan status mereka hanya sebagai warga Negara Tiongkok dengan secara resmi menolak kewarganegaraan Indonesia dalam waktu dua tahun.

Berdasarkan data yang kami dapatkan, $61 \%$ masyarakat etnis Tionghoa menggunakan suara hak pilih mereka dengan datang ke TPS. Hal tersebut didasari oleh kesadaran masyarakat etnis Tionghoa sebagai warga negara yang baik serta keinginan mereka untuk memilih pemimpinnya sendiri, sedangkan 39\% masyarakat etnis Tionghoa memilih golput karena beberapa alasan yang akan dijelaskan lebih lanjut pada diagram 1.3. Partisipasi untuk menggunkan suara hak pilih merupakan tindakan yang paling sederhana yang dapat dilakukan semua warga negara Indonesia, sehingga sangat disayangkan dan menjad perhatian penting bagi seluruh elemen mulai dari masyarakt, KPU, Bawaslu dalam menekan angka golput masyarakat etnis Tionghoa di Provinsi Bangka Belitung.

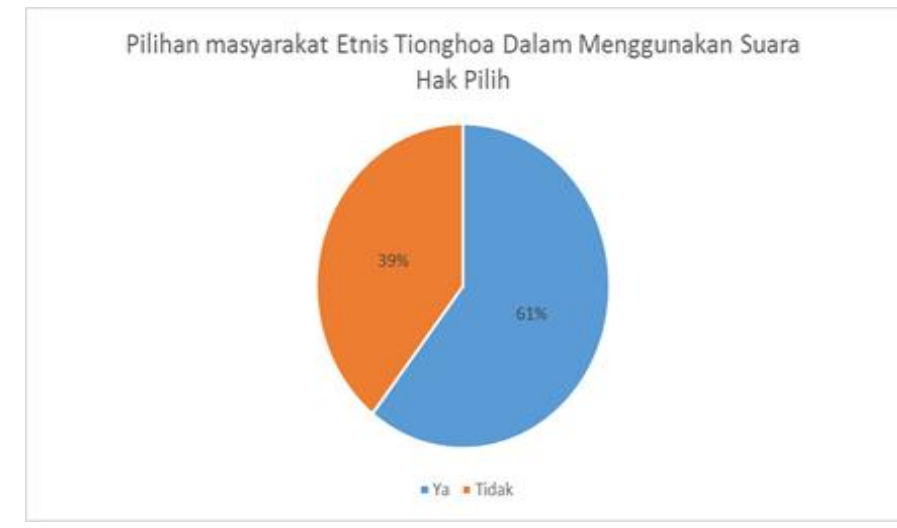

Diagram 1.1 Pilihan Masyarakat Etnis Tionghoa Dalam Menggunakan Hak Pilih

\author{
Scripta : Jurnal Ilmiah Mahasiswa \\ Fakultas Ilmu Sosial dan Ilmu Politik \\ Universitas Bangka Belitung \\ ISSN: 2656-9809
}


Setiap warga negara yang memasuki usia dewasa tentunya diharapkan memiliki partisipasi dalam kehidupan sosial di masyarakat. Kehidupan sosial itu salah satunya adalah berkiprah dalam politik. Namun, cara berkiprah dan berkecimpung di dunia politik dapat dilakukan dengan berbagai cara, salah satunya adalah mengetahui terlebih dahulu partisipasi seseorang. Partisipasi politik adalah kegiatan warganegara yang bertujuan untuk mempengaruhi pengambilan keputusan politik.

Terdapat beberapa alasan yang mendasari masyarakat etnis Tionghoa untuk memilih menggunakan suara hak pilih mereka, sebanyak $41 \%$ kesadaran diri yang menjadi kewajiban bagi seluruh warga negara Indonesia untuk datang ke TPS pada saat pencoblosan suara termasuk etnis Tionghoa, sementara $24 \%$ beralasan karena menyukai calon tersebut karena kesamaan etnis, agama, atau kharisma yang dimiliki oleh calon tersebut.

Sebesar 20\% masyarakat etnis Tionghoa diminta untuk memilih, pada umumnya responden yang baru pertama kali menggunakan suara hak pilih mereka atau yang biasa disebut kaum millenial, sementara sebesar $15 \%$ masyarakat etnis Tionghoa mengikuti pilihan orang lain seperi orang tua, teman, atau orang kepercayaan mereka. Dari keempat alasan tersebut dapat terlihat bahwa kesadaran etnis Tionghoa untuk menggunakan suara hak pilih mereka semakin meningkat, apa pun alasan mereka untuk memilih tidak menjadi persoalan yang besar karena bagaimana pun untuk menghidupkan demokrasi yang selama ini kita jalankan diperlukan partisipasi masyarakat untuk memilih. Jika dapat kita lihat kebelakang yakni pada saat masa orde baru masyaraka Tionghoa sangat dibatasi hak politiknya oleh negara.

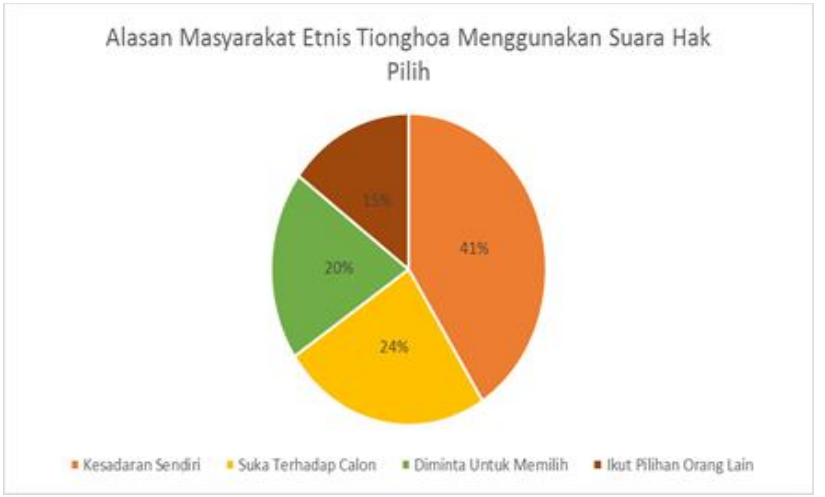

Diagram 1.2 Alasan Masyarakat Etnis Tionghoa Menggunakan Suara Hak Milik Mereka

Pasca "peristiwa Mei 1998" banyak sekali perubahan yang terjadi terkait dengan kelompok etnis Tionghoa. Perubahan tidak hanya terjadi pada perpolitikan nasional, tetapi

Scripta : Jurnal Ilmiah Mahasiswa Fakultas Ilmu Sosial dan Ilmu Politik Universitas Bangka Belitung ISSN: 2656-9809 
juga dalam hal "posisi”" etnis Tionghoa (secara sosial dan politik) di tengah masyarakat Indonesia umumnya. Perubahan penting di tingkat politik nasional, misalnya, adalah apa yang dilakukan Presiden Abdurrahman Wahid ketika beliau menerbitkan Inpres Nomor 6 pada tahun 2000 yang membatalkan peraturan sebelumnya (ada sejak 1967) yang melarang “ekspresi” kebudayaan Cina di ruang publik (Wibowo \& Thung, 2010).

Dari data yang kami dapatkan terdapat tiga alasan yang menyebabkan masyarakat etnis Tionghoa memilih untuk tidak menggunakan suara hak pilih mereka. Sebesar $50 \%$ masyarakat etnis Tionghoa bersikap apatis, apatisme atau masa bodoh dapat diartikan sebagai suatu sikap yang masa bodoh atau tidak peduli. Keapatisan masyarakat merupakan faktor internal yang utama, karena sikap apatis lahir dari dalam diri seseorang yang mendorong orang tersebut untuk berlaku apatis. Berdasarkan pengamatan di masyarakat, keapatisan masyarakat dibagi menjadi dua jenis. Pertama, apatis muncul karena seseorang memang tidak mau tahu dengan Pemilu. Sedangkan yang kedua, apatis justru muncul karena kekritisan seseorang dalam menilai paslon, visi dan misi, program, dan lain sebagainya yang kemudian mendorongnya untuk tidak memilih. Sebesar 30\% masyarakat etnis Tionghoa beralasan karena kesibukan yang tidak terlewatkan.

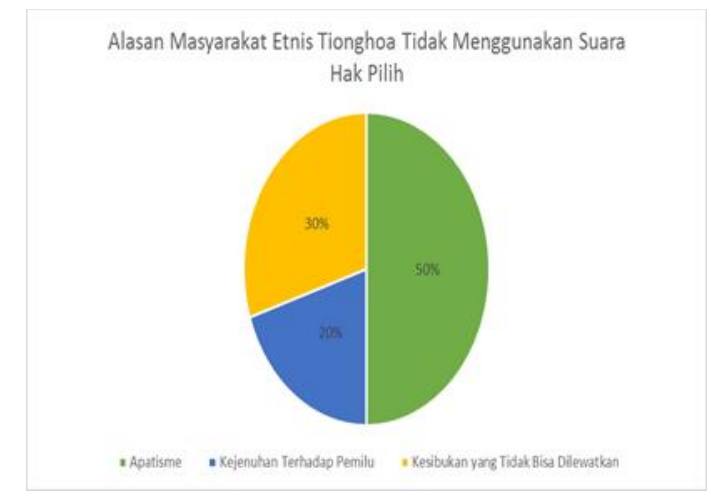

Diagram 1.3 Alasan Masyarakat Etnis Tionghoa Tidak Menggunakan Suara Hak Pilih

Kesibukan mereka menjadi salah satu faktor internal karena setiap warga memiliki kesibukannya masing-masing sehingga mereka malas untuk membicarakan soal politik atau pemerintahan, dan terkadang mereka tidak memiliki waktu untuk ikut dalam rapat yang diadakan oleh RT/ RW setempat. Beberapa informan menceritakan bahwa anak mereka yang mendapatkan undangan tidak memilih saat pemilihan karena sedang bersekolah di luar kota dan tidak memungkinkan kembali ke daerah asal mereka. Sementara $20 \%$ masyarakat etnis tionghoa merasa jenuh terhadap pemilu, hal tersebut

\author{
Scripta : Jurnal Ilmiah Mahasiswa \\ Fakultas Ilmu Sosial dan Ilmu Politik \\ Universitas Bangka Belitung \\ ISSN: 2656-9809
}


didasari karena mereka merasa tidak ada perubahan bagi hidup mereka apakah mereka menggunakan suara hak pilih mereka atau tidak.

Keterlibatan dalam aktivitas kampanye menjadi salah satu bagian partisipasi politik masyarakat etnis Tionghoa. Terdapat 24\% masyarakat etnis Tionghoa yang memilih untuk mengikuti kampanye mulai dari blusukan dari rumah kerumah hingga melakukan sosialisasi terhadap warga terkait calon yang diusung. Hal tersebut didasari oleh calon ataupun partai politik yang mereka sukai ataupun karena adanya program yang menguntungkan mereka. Sementara itu, $76 \%$ masyarakat etnis Tionghoa memilih untuk tidak mengikuti kampanye karena merasa hal tersebut tidak menguntungkan bagi mereka atau hanya membuang-buang waktu saja.

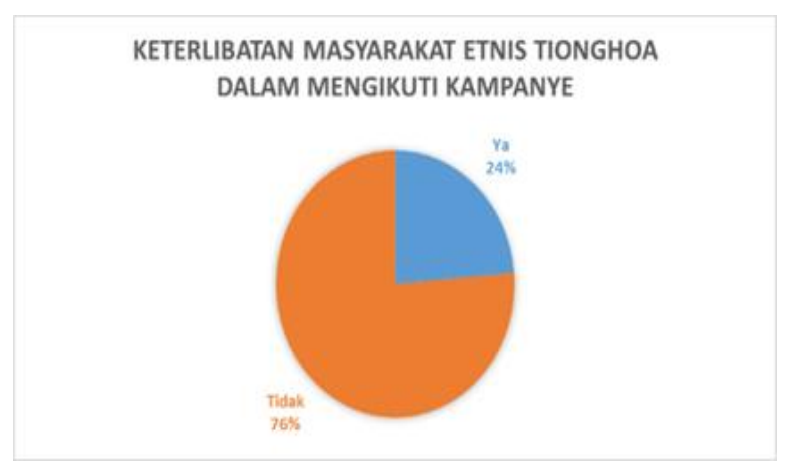

Diagram 1.4 Keterlibatan Masyarakat Etnis Tionghoa Dalam Mengikuti Kampanye

\section{SIMPULAN DAN SARAN}

\section{Simpulan}

Ciri sebuah negara demokratis adalah seberapa besar negara melibatkan masyarakat dalam perencanaan maupun pelaksanaan pemilihan umum. Sebab partisipasi politik masyarakat (pemilih) merupakan aspek penting dalam sebuah tatanan negara demokrasi. Dalam hubungannya dengan demokrasi, partisipasi politik berpengaruh terhadap legitimasi oleh masyarakat terhadap jalannya suatu pemerintahan. Dalam Pemilu misalnya partisipasi politik berpengaruh terhadap legitimasi masyarakat kepada calon atau pasangan calon yang terpilih. Setiap masyarakat memiliki preferensi dan kepentingan masing-masing untuk menentukan pilihan mereka dalam Pemilu. Indonesia yang memiliki masyarakat multikulturalisme memberikan hak politiknya terhadap semua warga negara tanpa melihat etnis, ras, suku, dan agama untuk berpartisipasi dalam pemilu. Salah satu dari sekian banyak etnis yang ada di Indonesia yakni Etnis Tionghoa. 
Di Bangka Belitung sendiri, etnis Tionghoa turut berperan penting dalam roda pemerintahan termasuk dalam pemilihan umum. Maka dari penelitian ini, dapat dilihat tingkat partisipasi politik etnis Tionghoa pada Pemilu tahun 2019 di Bangka Belitung yakni $61 \%$ masyarakat etnis Tionghoa menggunakan suara hak pilih mereka dengan datang ke TPS dan sisanya yakni 39\% masyarakat etnis Tionghoa memilih untuk tidak menggunakan suara hak pilih mereka. Keterlibatan dalam aktivitas kampanye yang dilakukan oleh masyarakat etnis Tionghoa juga hanya berkisar $24 \%$ sedangkan $76 \%$ nya memilih untuk tidak mengikuti aktivitas kampanye karena dinilai tidak menguntungkan mereka. Sehingga dapat disimpulkan bahwa partisipasi masyarakat etnis Tionghoa di Bangka Belitung masih terbilang rendah dan belum maksimal pada Pemilu tahun 2019, akan tetapi masyarakat etnis Tionghoa terus menunjukan eksistensi politiknya pada Pemilu tahun 2019 dibandingkan dengan Pemilu sebelumnya. Sehingga bukan tidak mungkin masyarakat etnis Tionghoa akan mengalami kemajuan peningkatan partisipasi sejalan dengan semakin membaiknya sistem demokrasi di Indonesia termasuk di Bangka Belitung.

\section{Saran}

Ada baiknya untuk penelitian-penelitian selanjutnya terkait partisipasi politik etnis Tionghoa terutama di Bangka Belitung agar peneliti memperbanyak sumber informasi maupun referensi serta dapat melakukan wawancara dengan sumber yang kompeten agar penelitian selanjutnya dapat lebih baik dan lengkap lagi. 


\section{DAFTAR PUSTAKA}

Liando, M.Daud. (2016). Pemilu dan Partisipasi Politik Masyarakat (Studi Pada Pemilihan Anggota Legislatif Dan Pemilihan Presiden Dan Calon Wakil Presiden Di Kabupaten Minahasa Tahun 2014). Jurnal LPPM, 3 (3).

Gleko Petrus, dkk. (2017). Strategi Komisi Pemilihan Umum Dalam Upaya Meningkatkan Partisipasi Politik Masyarakat Pada Pemilihan Umum Kepala Daerah. JISIP Jurnal Ilmu sosial dan Ilmu Politik, 6 (1), 2442-6962.

Lihardja Ninawati, dkk. (2017). Partisipasi Politik Generasi Muda Tionghoa Paska Orde Baru. Conference On Management and Behavioral Studies. 2541-3406.

Sartika Patricia. (2017). Partisipasi Pemilih Etnis Tionghoa di Kelurahan Tawang Mas Dalam Pemilu Walikota dan Wakil Walikota Semarang Tahun 2015. Program studi Ilmu Pemerintahan Universitas Diponegoro. 